\title{
ENERGY EFFICIENCY OPPORTUNITIES IN THE U.S. PULP AND PAPER INDUSTRY
}

\author{
Klaas Jan Kramer, Eric Masanet, and Ernst Worrell \\ Lawrence Berkeley National Laboratory \\ 1 Cyclotron Road, Building 90R4000 \\ Berkeley, California, United States, 94720
}

\begin{abstract}
The U.S. pulp and paper industry consumes over $\$ 7$ billion worth of purchased fuels and electricity per year. Energy efficiency improvement is an important way to reduce these costs and to increase predictable earnings, especially in times of high energy price volatility. There are a variety of opportunities available at individual plants in the U.S. pulp and paper industry to reduce energy consumption in a cost-effective manner. This paper provides a brief overview of the U.S. EPA ENERGY STAR ${ }^{\circledR}$ for Industry energy efficiency guidebook (a.k.a. the "Energy Guide") for pulp and paper manufacturers. The Energy Guide discusses a wide range of energy efficiency practices and energy-efficient technologies that can be implemented at the component, process, facility, and organizational levels. Also provided is a discussion of the trends, structure, and energy consumption characteristics of the U.S. pulp and paper industry along with a description of the major process technologies used within the industry. Many energy efficiency measure descriptions include expected savings in energy and energy-related costs, based on case study data from real-world applications in pulp and paper mills and related industries worldwide. The information in this Energy Guide is intended to help energy and plant managers in the U.S. pulp and paper industry reduce energy consumption in a cost-effective manner while maintaining the quality of products manufactured. Further research on the economics of all measures—as well as on their applicability to different production practices-is needed to assess their cost effectiveness at individual plants.
\end{abstract}

\section{THE ENERGY STAR ${ }^{\circledR}$ FOR INDUSTRY PROGRAM}

ENERGY STAR is a voluntary government program that offers businesses and consumers a broad range of resources on the best in energy efficiency to help save money and protect the environment. The ENERGY STAR for Industry Program works directly with U.S. manufacturers to help them improve competitiveness through improved energy management, increased energy efficiency, and reduced environmental impact.

To date, the ENERGY STAR for Industry program has established ten different Industrial Focuses in partnership with specific energy-intensive industries in the United States. Current and past Industrial Focuses include motor vehicle manufacturing, corn refining, cement manufacturing, breweries, petroleum refining, glass manufacturing, pharmaceutical manufacturing, food processing, petrochemical manufacturing, and pulp and paper manufacturing. Many of the companies participating in these Industrial Focuses have reported significant cost and energy savings and have gone on to receive recognition as leaders in energy efficiency and environmental performance.

As part of each Industrial Focus, participating companies have access to energy professionals who offer assistance to plant energy managers and share proven, non-proprietary approaches for improving corporate energy management. An annual Industrial Focus forum is also held, where companies can openly discuss non-confidential issues confronting their energy management programs. Lastly, for many industries an energy use benchmarking tool—the Energy Performance Indicator (EPI)—is also developed. For more information on the program, please visit www.energystar.gov/industry.

ENERGY STAR also offers each Industrial Focus a detailed Energy Guide, which discusses a wide variety of energy efficiency opportunities applicable to plants within the focus industry. The Energy Guides are researched and authored by Lawrence Berkeley National Laboratory (LBNL) in partnership with ENERGY STAR and participating focus companies. The Energy Guides are used by energy managers to identify 
areas for energy efficiency improvements, to evaluate potential energy improvement options, to develop action plans and checklists for plant-level energy management, and to educate company employees on the importance of and actions for improved energy efficiency.

The Energy Guide for the U.S. pulp and paper industry contains detailed information on over 125 energy efficient technologies and energy management practices applicable to the typical pulp and paper mill in the following categories:

- Energy management programs and systems

- Steam systems

- Motor systems

- Pumps

- Fan systems

- Compressed air systems

- Raw material preparation

- Chemical pulping, bleaching, and chemical recovery

- Mechanical pulping

- Papermaking

- Emerging energy efficient technologies

Given the importance of water as a resource in pulp and paper making, the Energy Guide also contains a chapter on proven measures for plant-level water efficiency. This article provides a brief summary and an advance preview of information contained in the forthcoming Energy Guide [1]

\section{THE U.S. PULP AND PAPER INDUSTRY}

The U.S. pulp and paper industry - defined in the Energy Guide as facilities engaged in the manufacture of pulp, paper and paperboard (i.e., NAICS 3221) - is an important industry from both an economic and an energy use perspective. In 2006, the industry generated nearly $\$ 79$ billion in product shipments and employed around 139,000 people directly in nearly 600 mills. The industry spent roughly $\$ 7.5$ billion on purchased fuels and electricity in 2006; around $\$ 4.7$ billion of this was for purchased fuels and around \$2.8 billion of this was for purchased electricity [2,3] Because the costs of electricity and natural gas are rising rapidly in the United States, energy efficiency improvements are becoming an increasingly important focus area in the U.S. pulp and paper industry for managing costs and maintaining competitiveness.

Pulp mills are located in regions of the United States where trees are harvested from abundant forests or tree farms. More than $70 \%$ of U.S. wood pulp capacity is located in the South Atlantic and South Central regions, close to the source of wood fibers [4]. Other key pulp mill locations include the Northwest, Northeast, and North Central regions [5]. Pulp mills that process recycled fiber are generally located near large population centers, which are key sources of wastepaper.

Paper and paperboard mills are more widely distributed, but in general they are located near pulping operations and/or close to large population centers where final consumers are located. Over $50 \%$ of paper and paperboard mills are located in the Northeast and North Central regions, close to final consumers [4].

Wisconsin, Alabama, Pennsylvania, Georgia, and South Carolina are the top five producers of pulp and paper products, based on industry value of shipments in 2006. Wisconsin ranks first by a significant margin, accounting for $10 \%$ of industry value of shipments, $11 \%$ of industry employment, and $10 \%$ of industry establishments [2, 3].

Pulp and paper are commodities and therefore their prices are vulnerable to global competition. In order to maintain market share in an increasingly competitive global market, U.S. pulp and paper companies have undergone a significant number of acquisitions and mergers in recent years. For example, between 1997 and 2002 at least 12 important mergers occurred with a combined value of around $\$ 55$ billion [5]. In all pulp and paper industry sub-sectors, the four largest companies account for at least half of industry value of shipments [6]. 
Virgin wood is used to manufacture a variety of pulps in the United States, most importantly chemical wood pulp, mechanical wood pulp, semi-chemical wood pulp, and dissolving wood pulp. Total U.S. production of wood pulp increased from 40 million tonnes (Mt) in 1976 to 56 Mt in 2006; however, current U.S. wood pulp production is around 15\% lower than its 1994 peak of $66 \mathrm{Mt}$ [7].

In 1976, chemical pulping accounted for $78 \%$ of U.S. wood pulp production, while mechanical and other pulping accounted for $10 \%$ and $12 \%$, respectively. While total wood pulp production has increased significantly since 1976, the composition of U.S. wood pulp production has changed little. Chemical wood pulp production has become more dominant and comprises nearly $85 \%$ of U.S. wood pulp production in 2006, while mechanical pulping now represents only around $8 \%$ of production.

In addition to the various types of wood pulp, recovered paper is used as a raw material in producing paper products. Recovered paper use in the United States pulp and paper industry has grown from $14 \mathrm{Mt}$ in 1976 to nearly $47 \mathrm{Mt}$ in 2006, which represents a growth of more than 200\% [7].

Figure 1 depicts the trends in the production of paper and paperboard products in the United States between 1976 and 2006 [7]. Printing and writing paper, wrapping and packaging paper, and paperboard accounted for around $80 \%$ of total U.S. production by mass in 2006. The remaining production was made up by newsprint, household and sanitary paper, and paper and paperboard not elsewhere specified (NES), which is a catch-all category that includes Kraft paper, construction paper, blotting paper, filter paper, and other miscellaneous paper types.

\section{Figure 1: U.S. paper and paperboard product production, 1976 -2006}

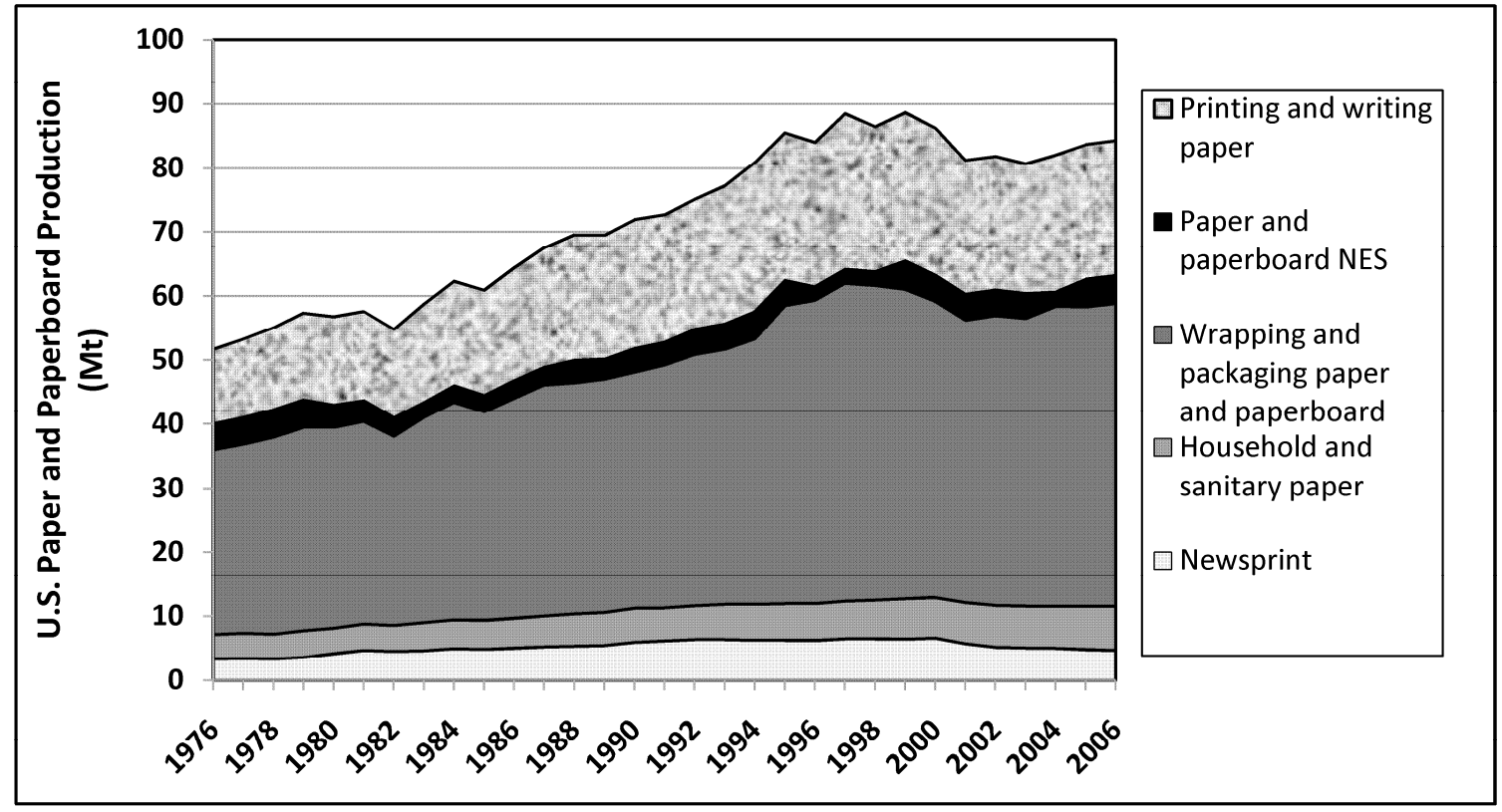

Source: [7]

Total U.S. production of all paper products increased from $52 \mathrm{Mt}$ in 1976 to $84 \mathrm{Mt}$ in 2006. However, U.S. production has fluctuated between $84 \mathrm{Mt}$ and $88 \mathrm{Mt}$ since 1999. The most significant growth in production since 1976 occurred in the printing and writing paper and household and sanitary paper categories, which both grew by around $80 \%$. Newsprint production peaked at nearly $7 \mathrm{Mt}$ in 2000, but has since decreased by $30 \%$ (to $4.7 \mathrm{Mt}$ in 2006).

\section{ENERGY USE IN THE U.S. PULP AND PAPER INDUSTRY}

Energy represents a significant cost to the U.S. pulp and paper industry. In 2006, the industry spent roughly $\$ 7.5$ billion on purchased fuels and electricity [2]. Around $\$ 4.7$ billion of this was for purchased 
fuels and around \$2.8 billion of this was for purchased electricity. Energy costs are a sizeable fraction of operating costs, equal to roughly $20 \%$ of the industry's total cost of materials.

The U.S. pulp and paper industry is also among the largest energy consuming industries in the United States. As of 2006, the industry (NAICS 3221) accounted for over $8 \%$ of the purchased fuels and over $9 \%$ of the electricity consumption of the entire U.S. manufacturing sector [2]. Moreover, purchased fuels represent less than half of the fuels consumed by U.S. pulp and paper mills, since much on-site energy is generated using waste wood and bark (i.e., hog fuel) and spent cooking chemicals (i.e., black liquor) [5, 9].

Electricity is used throughout the typical pulp and paper mill to power motors and machine drives, conveyors, and pumps, as well as building operations such as lighting and ventilation systems. The largest use of fuels is in boilers to generate steam for use in pulping, evaporation, papermaking, and other operations. Black liquor is the dominant fuel for boilers in the pulp and paper industry, followed by hog fuel and natural gas, and to a lesser extent, coal [10]. Natural gas and oil are typically used in lime kilns [9].

The major processes employed in the manufacture of pulp and paper products include raw materials preparation, pulping (chemical, semi-chemical, mechanical, and waste paper), bleaching, chemical recovery, pulp drying, and paper making. Figure 2 provides a flow diagram of these processes and their use of fuels, steam, and electricity [11].

Figure 2: Schematic of major pulp and paper manufacturing processes

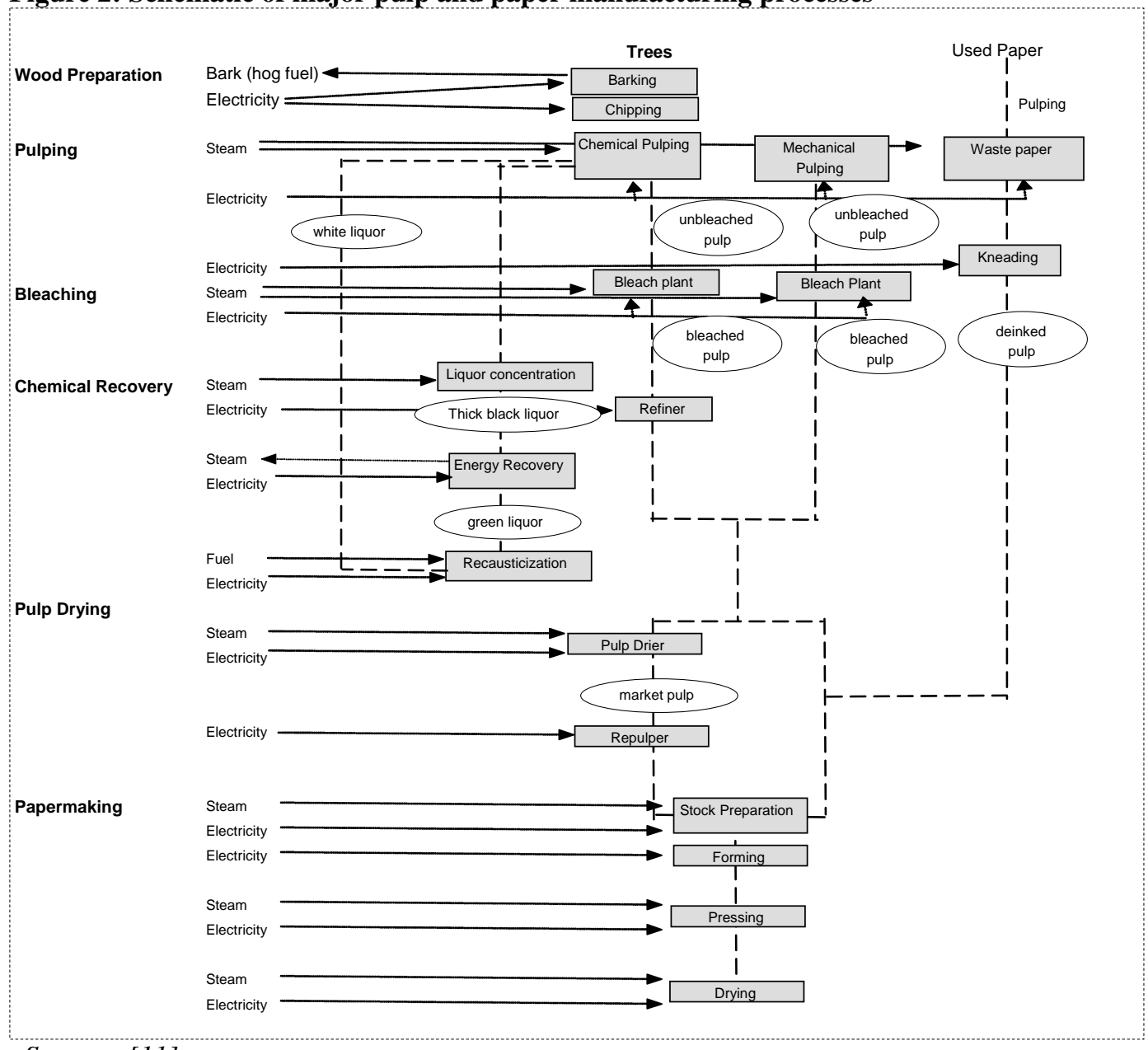

Source: [11] 
Figure 3 plots the costs of purchased electricity and fuels in the U.S. pulp and paper industry over the period 1997 to 2006 [2, 12, 13]. While the total cost of purchased electricity remained fairly steady over this period, the total cost of purchased fuels increased by around 50\% (in nominal dollars). Natural gas accounts for roughly two-thirds of the fuel purchased by the U.S. pulp and paper industry, with coal and fuel oil comprising most of the remaining fuel purchases [9]. The steep rise in purchased fuel cost may therefore be explained in part by the similarly steep rise in U.S. industrial natural gas prices that occurred over the same period (\$3.59 per $1000 \mathrm{ft} 3$ in 1997 versus $\$ 7.86$ per $1000 \mathrm{ft} 3$ in 2006) [14].

Figure 3: Cost of purchased fuels and electricity in the U.S. pulp and paper industry, 1997 to 2006

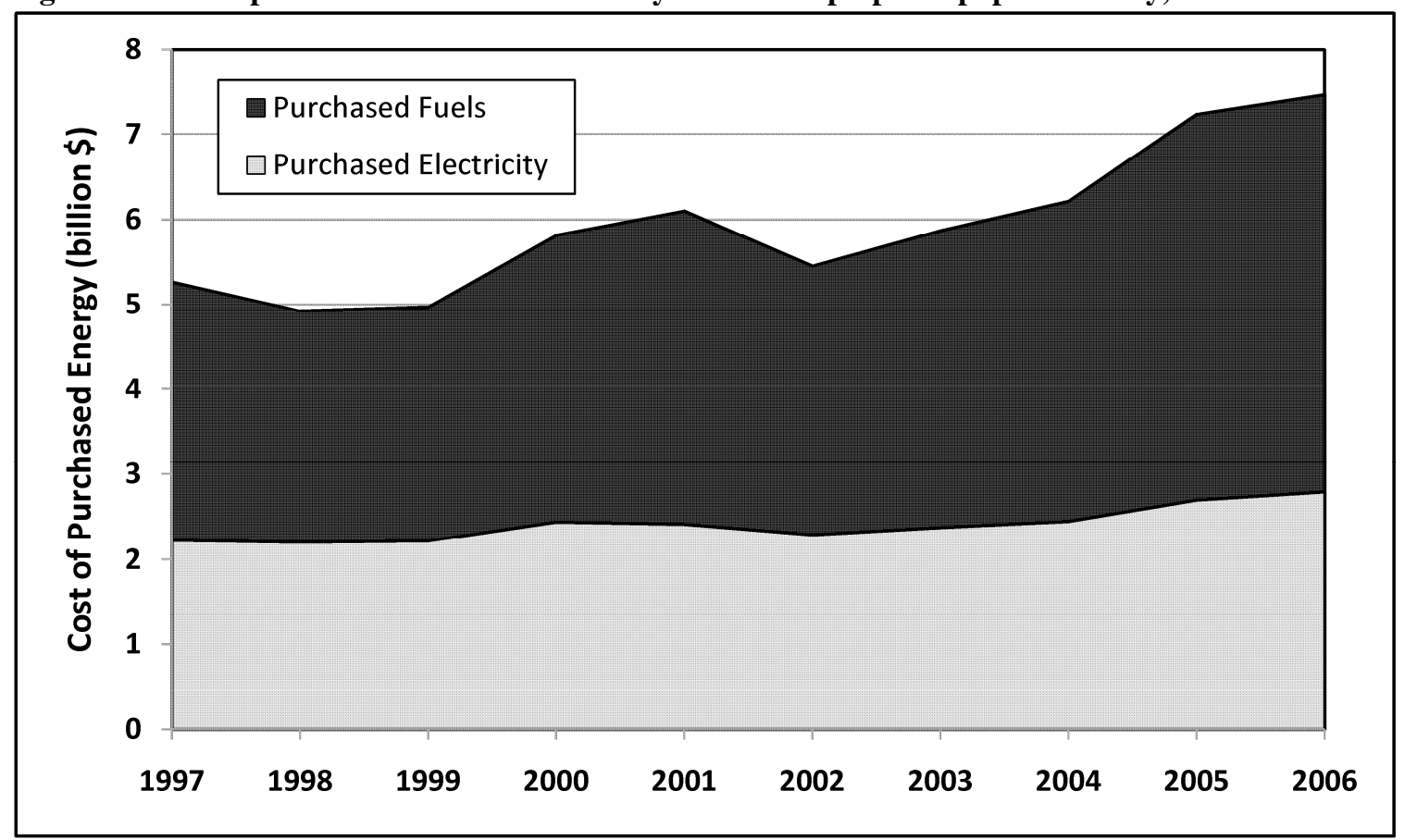

Sources: $[2,12,13]$

The U.S. pulp and paper industry is the single largest self-generator of electricity in the U.S. manufacturing sector. Thus, the electricity purchases illustrated in Figure 3 represent only a portion of the industry's electricity use. In 2002, the industry generated over 50 billion kWh of electricity on-site, which accounted for around $40 \%$ of total industrial on-site electricity generation in the United States [15].

Table 1 summarizes estimates of the total energy use of the U.S. pulp and paper industry as of 2002, which is the latest year for which detailed industry fuel use data are available from the U.S. Department of Energy [15]. In 2002, the industry consumed over 2,200 trillion British thermal units (TBtu) of energy, which accounted for around $14 \%$ of all the fuel consumed by the U.S. manufacturing sector. The data in Table 1 are ranked in order of fuel type use importance from left to right. 
Table 1: Energy use of the U.S. pulp and paper industry (NAICS 3221) in 2002 (TBtu)

\begin{tabular}{|c|c|c|c|c|c|c|c|c|c|c|}
\hline $\begin{array}{l}\text { NAICS } \\
\text { Code }\end{array}$ & Sub-Sector & Total & $\begin{array}{l}\text { Black } \\
\text { Liquor }\end{array}$ & $\begin{array}{l}\text { Natural } \\
\text { Gas }\end{array}$ & $\begin{array}{c}\text { Wood \& } \\
\text { Bark }\end{array}$ & Coal & $\begin{array}{c}\text { Net } \\
\text { Electricity }\end{array}$ & $\begin{array}{c}\text { Residual } \\
\text { Oil }\end{array}$ & $\begin{array}{c}\text { Distillate } \\
\text { Oil }\end{array}$ & Other \\
\hline 32211 & Pulp mills & 224 & 140 & 24 & 33 & 1 & 5 & 5 & 5 & 11 \\
\hline 322121 & $\begin{array}{l}\text { Paper (except } \\
\text { newsprint) mills }\end{array}$ & 1,002 & 336 & 206 & 114 & 139 & 78 & 47 & 4 & 78 \\
\hline 322122 & Newsprint mills & 94 & 9 & 16 & 14 & 11 & 38 & 7 & & \\
\hline 32213 & Paperboard mills & 907 & 335 & 188 & 158 & 83 & 56 & 34 & 4 & 49 \\
\hline \multicolumn{2}{|r|}{ Total } & 2,227 & 820 & 434 & 319 & 234 & 177 & 93 & 13 & 138 \\
\hline \multicolumn{2}{|r|}{$\%$ of Total } & & $37 \%$ & $19 \%$ & $14 \%$ & $11 \%$ & $8 \%$ & $4 \%$ & $1 \%$ & $6 \%$ \\
\hline
\end{tabular}

Source: Adapted from $[15,51]$

It can be seen that the use of two by-products of the pulp and paper production process-black liquor and hog fuel (i.e., wood and bark)-meet over $50 \%$ of the industry's annual energy requirements. This selfgeneration significantly reduces the industry's dependence on fossil fuel inputs and purchased electricity, with the added benefits of reduced raw material costs (i.e., avoided pulping chemical purchases) and reduced waste generation. Natural gas and coal comprise the majority of the remaining fuel used by the industry.

Black liquor, hog fuel, coal, and residual oils are used exclusively as boiler fuels to generate power and to produce steam for use in the various pulping and papermaking processes [16]. Black liquor is combusted in a recovery boiler, which is designed for the dual purpose of generating steam and recovering inorganic smelt for regeneration into white liquor. Because of the low heat contents of black liquor and hog fuel, the efficiencies of boilers that combust these fuels are around 65\% [9]. Natural gas is also used as a boiler fuel, but it is also used in significant quantities for direct process heating in lime kilns and limited drying applications (e.g., coating and tissue drying) [16]

In the manufacture of pulp, evaporation, cooking (includes digestion through washing for chemical pulps), and chemical preparation are the most energy intensive processes. Steam is used in significant quantities for nearly every process, but most notably in the evaporation, cooking, and bleaching processes for process heat. The sole use of direct fuel is the chemicals preparation process (in the lime kiln) [16].

Drying is by far the most energy intensive step associated with paper machine operations, accounting for roughly two-thirds of total papermaking energy use. U.S. papermaking requires in total between around 6-9 million Btu per ton in integrated mills, depending on the paper grade [16].

\section{ENERGY EFFICIENCY IMPROVEMENT OPPORTUNITIES}

Many opportunities exist within the U.S. pulp and paper industry to reduce energy consumption while maintaining or enhancing productivity. Ideally, energy efficiency opportunities should be pursued in a coordinated fashion at multiple levels within a facility. At the component and equipment level, energy efficiency can be improved through regular preventative maintenance, proper loading and operation, and replacement of older components and equipment with higher efficiency models (e.g., high efficiency motors) whenever feasible. At the process level, process control and optimization can be pursued to ensure that production operations are running at maximum efficiency. At the facility level, the efficiency of space lighting and ventilation can be improved while total facility energy inputs can be minimized through process integration, where feasible. Lastly, at the level of the organization, energy management systems can be implemented to ensure a strong corporate framework exists for energy monitoring, target setting, employee involvement, and continuous improvement.

The Energy Guide for pulp and paper manufacturers discusses some of the most significant energy efficiency measures at the component, process, facility and organization levels. The focus of the Energy Guide is on energy efficiency measures that are proven, cost effective, and available for implementation today. Whenever possible, measure descriptions include case studies of pulp and paper mills that have successfully implemented the measure, both in the United States and abroad. Many case studies include 
specific energy and cost savings data as well as typical investment payback periods. For measures where data are not available for pulp and paper mills, the Energy Guide also presents case study data from other similar industries. Lastly, for most measures references to the technical literature and online resources are provided, which can be consulted for further information.

The Energy Guide also presents a brief overview of selected emerging energy-efficient technologies, which have recently been developed or commercialized and hold promise for reducing energy use in the U.S. pulp and paper industry in the near future.

At individual pulp and paper mills, the actual payback period and savings associated with a given measure will vary depending on facility activities, configuration, size, location, and operating characteristics. Thus, the values presented in the Energy Guide are offered as guidelines. Further research on the economics of all measures-as well on as their applicability to different production practices-is needed to assess their cost effectiveness at individual plants.

The Energy Guide classifies energy efficiency measures into three primary categories:

- Cross-cutting measures, which are measures applicable to cross-cutting systems (e.g., motors and pumps) that are common across industries.

- Process-specific measures, which are measures applicable to processes specific to the pulp and paper industry (e.g., pulping).

- Emerging technologies, which are energy efficient technologies that hold significant promise for commercialization and/or substantial market penetration in the next several years.

Table 2 provides a summary of some of the key cross-cutting measures that are presented in the Energy Guide [1].

The following sections highlight a few of the key efficiency measures discussed in the Energy Guide, with case studies from real-world applications of each measure. 
Table 2: Summary of cross-cutting energy efficiency measures

\begin{tabular}{|c|c|}
\hline \multicolumn{2}{|c|}{$\begin{array}{l}\text { Energy Management Programs and Systems } \\
\end{array}$} \\
\hline Energy management programs & Energy teams \\
\hline Energy monitoring and control systems & \\
\hline \multicolumn{2}{|c|}{ Steam Systems } \\
\hline \multicolumn{2}{|c|}{ Boilers } \\
\hline Boiler process control & Minimizing blow down \\
\hline Reduction of flue gas quantities & Blow down steam recovery \\
\hline Reduction of excess air & Flue gas heat recovery \\
\hline Improved boiler insulation & Burner replacement \\
\hline Condensate return & \\
\hline \multicolumn{2}{|c|}{ Steam Distribution Systems } \\
\hline Steam distribution controls & Steam trap maintenance \\
\hline Improved insulation & Steam trap monitoring \\
\hline Insulation maintenance & Leak repair \\
\hline Steam trap improvement & Flash steam recovery \\
\hline \multicolumn{2}{|c|}{ Process Integration and Self-Generation } \\
\hline Pinch analysis & Steam injected gas turbines \\
\hline Cogeneration of heat and power (CHP) & Steam expansion turbines \\
\hline \multicolumn{2}{|c|}{ Motor Systems } \\
\hline Motor management plan & Adjustable-speed drives (ASDs) \\
\hline Strategic motor selection & Power factor correction \\
\hline Maintenance & Minimizing voltage unbalance \\
\hline Properly sized motors & \\
\hline \multicolumn{2}{|c|}{ Pump Systems } \\
\hline Pump system maintenance & Avoiding throttling valves \\
\hline Pump system monitoring & Replacement of belt drives \\
\hline Pump demand reduction & Proper pipe sizing \\
\hline Controls & Precision casting, surface coating or polishing \\
\hline High-efficiency pumps & Sealings \\
\hline Properly sized pumps & Curtailing leakages through clearance reduction \\
\hline Multiple pumps for variable loads & Adjustable-speed drives (ASDs) \\
\hline Impeller trimming & Dry vacuum pumps \\
\hline \multicolumn{2}{|c|}{ Fans } \\
\hline Maintenance & High efficiency belts (cog belts) \\
\hline Properly sized fans & Duct leakage repair \\
\hline $\begin{array}{l}\text { Adjustable-speed drives (ASDs) and improved } \\
\text { control }\end{array}$ & \\
\hline \multicolumn{2}{|c|}{$\begin{array}{l}\text { Compressed Air Systems } \\
\end{array}$} \\
\hline System improvements & Improved load management \\
\hline Maintenance & Pressure drop minimization \\
\hline Monitoring & Inlet air temperature reduction \\
\hline Leak reduction & Controls \\
\hline Turning off unnecessary compressed air & Properly sized pipe diameter \\
\hline Modification of system in lieu of increased pressure & Heat recovery \\
\hline $\begin{array}{l}\text { Replacement of compressed air by alternative } \\
\text { sources }\end{array}$ & Natural gas engine-driven compressors \\
\hline
\end{tabular}




\section{EXAMPLES OF CROSS-CUTTING EFFICIENCY MEASURES}

\section{Steam systems}

Steam systems are by far the most significant end use of energy in the U.S. pulp and paper industry. Over $80 \%$ of the energy consumed by the industry is in the form of boiler fuel [16]. Energy efficiency improvements to steam systems therefore represent the most significant opportunities for energy savings in pulp and paper mills. According to a recent study by the U.S. DOE, the U.S. pulp and paper industry could reduces its fuel use by $12.5 \%$, and save 278 TBtu, by implementing best practice steam system improvement opportunities [17].

Several examples of steam system measures presented in the Energy Guide are provided below.

Boiler process control. Flue gas monitors maintain optimum flame temperature and monitor carbon monoxide (CO), oxygen, and smoke. The oxygen content of the exhaust gas is a combination of excess air (which is deliberately introduced to improve safety or reduce emissions) and air infiltration. By combining an oxygen monitor with an intake airflow monitor, it is possible to detect even small leaks. A small $1 \%$ air infiltration will result in $20 \%$ higher oxygen readings. A higher CO or smoke content in the exhaust gas is a sign that there is insufficient air to complete fuel burning. Using a combination of CO and oxygen readings, it is possible to optimize the fuel/air mixture for high flame temperature (and thus the best energy efficiency) and lower air pollutant emissions.

Typically, this measure is financially attractive only for large boilers, because smaller boilers often will not make up the initial capital cost as easily. Several case studies indicate that the average payback period for this measure is around 1.7 years [18].

At the Appleton Paper mill in West Carrolton, Ohio, three boilers (two fired by coal, one by natural gas) produce 250,000 pounds per hour of steam for several heating and drying processes. An energy audit of the mill found that the mill's boiler control system did not provide continuous monitoring or control of combustion air. The audit team recommended that the mill install a control system to measure, monitor, and control oxygen and carbon monoxide levels on it coal-fired boilers, given that these boilers operated near full capacity and would reap the greatest benefits of improved control. This measure was estimated to save nearly $\$ 475,000$ in annual energy costs; at an investment cost of $\$ 200,000$, the payback period was less than six months [19].

Reduction of excess air. Boilers must be fired with excess air to ensure complete combustion and to reduce the presence of carbon monoxide in the unburned fuel in exhaust gases. When too much excess air is used to burn fuel, energy is wasted because excessive heat is transferred to the air rather than to the steam. Air slightly in excess of the ideal stochiometric fuel-to-air ratio is required for safety and to reduce emissions of nitrogen oxides (NOx), but approximately 15\% excess air (around 3\% excess oxygen) is generally adequate $[20,21]$. Most industrial boilers already operate at $15 \%$ excess air or lower, and thus this measure may not be widely applicable [22]. However, if a boiler is using too much excess air, numerous industrial case studies indicate that the payback period for this measure is less than one year [18].

Examples of improvements to reduce excess air include changing automatic oxygen control set points, periodic tuning of single set point control mechanisms, installing automatic flue gas monitoring and control, fixing broken baffles, and repairing air leaks into the boiler. The U.S. DOE estimates that U.S. pulp and paper plants could reduce boiler fuel use by around $2.3 \%$ through application of this measure (it was assumed that this measure would be feasible at around one-third of U.S. pulp and paper mills) [17]. The estimated average payback period for this measure was 5 months.

As part of the U.S DOE's Save Energy Now Program, an audit was conducted at the Boise Cascade mill in Jackson, Alabama. This Kraft pulp mill produces around 1,000 tons of paper per day and uses (among other boilers) a combination fuel boiler that typically burns green wood and bark. Combustion tuning of this boiler reduced flue gas oxygen concentrations from the $8-12 \%$ range to the 6- 7\% range. The savings in green wood was reported to be around \$70,000 per year [23]. 
Similar benefits were predicted at the West Linn Paper Company's coated paper mill in West Linn, Oregon. A U.S. DOE audit found that by adjusting boiler oxygen trim controls to lower the oxygen levels to between 2.5-3\%, boiler efficiency improvements would save 15,500 MMBtu per year at a cost savings of around $\$ 118,000$ [24].

Blow down steam recovery. Boiler blow down is important for maintaining proper steam system water properties. However, blow down can result in significant thermal losses if the steam is not recovered for beneficial use. Blow down steam is typically low grade, but can be used for space heating and feed water preheating. In addition to energy savings, blow down steam recovery may reduce the potential for corrosion damage in steam system piping. Examples of blow down steam recovery in the pulp and paper industry suggest a payback period of around 12 to 18 months for this measure [25].

The U.S. DOE estimates that the installation of continuous blow down heat recovery systems is feasible at around $20 \%$ of U.S. pulp and paper mills, and would reduce boiler fuel use by around $1.2 \%$ [17].

For example, a boiler blow down heat recovery project at Augusta Newsprint Company's Augusta, Georgia, mill led to significant energy and cost savings. An existing boiler blow down system was modified by installing a plate-and-tube heat exchanger and associated piping to recover energy from the mill's continuous blowdown stream from the boiler blow down flash tank. The project resulted in annual energy savings of 14,000 MMBtu, with annual fuel cost savings of over $\$ 30,000$. The period of payback for this project was about six months [26].

Similarly impressive savings were identified by Boise Cascade at two different mills. At the company's mill in International Falls, Minnesota, a plant-wide assessment estimated that the pursuit of blow down heat recovery (as opposed to the current practice of venting blow down to atmosphere) could save the mill around \$370,000 per year [27]. At the company’s mill in Jackson, Alabama, it was estimated that a significant amount of additional thermal energy could be recovered from the liquid blow down rejected from the flash vessel. If a second stage of blow-down energy recovery were installed on the remaining boilers, additional blow down recover energy savings of $\$ 100,000$ per year were projected [23].

Steam distribution controls. Steam demand can be interrupted due to changing operating procedures at steam using processes (e.g., paper machine or turbines), or due to operational failures (e.g., a sheet breakage). This can lead to the dumping of excess steam or additional fuel use for back-up boilers. Modern control systems have been deployed to better manage a steam system, reducing the need for back-up steam capacity or the need to dump steam.

For example, Aylesford Newsprint Ltd. in the United Kingdom implemented a second-generation control system for their steam system, which consisted of three paper machines, two natural gas-fired gas turbines based combined heat and power (CHP) units, one steam turbine, and a steam accumulator. The system is model-based predictive control system to manage steam loads better. The system resulted in a 95\% reduction of steam venting and a $70 \%$ reduction in fuel use for back up steam generation, with a payback period of less than 6 months [28].

\section{Motor systems}

Motor-driven systems are by far the most significant consumer of electrical energy in a typical U.S. pulp and paper mill. As of 2002, motor-driven systems accounted for around $90 \%$ of all the electricity used by the U.S. pulp and paper industry [15]. Furthermore, pumps, fans, and materials processing equipment account for the majority (over 70\%) of motor-driven systems electricity use in the typical U.S. mill [29]. Other important uses of electricity in pulp and paper manufacturing include materials handling systems (e.g., conveyors) and compressed air systems.

Efficiency improvements to motor-driven systems can therefore lead to significant energy savings in most pulp and paper mills. The U.S. DOE estimates (as of 2002) that efficiency improvements to basic components of motor-driven systems in the U.S. pulp and paper industry could lead to electricity savings of $14 \%[29]$. 
Adjustable speed drives (ASDs). Adjustable-speed drives better match speed to load requirements for motor operations, and therefore ensure that motor energy use is optimized to a given application. Adjustable-speed drive systems are offered by many suppliers and are available worldwide. Worrell et al. [30] provide an overview of savings achieved with ASDs in a wide array of applications; typical energy savings are shown to vary between $7 \%$ and $60 \%$. Industrial case studies from the IAC database suggest that the payback period associated with the installation of ASDs in a number of different applications ranges between roughly one and three years [18].

The Augusta Newsprint mill (part of a joint partnership between Abitibi Consolidated and the Woodbridge Company, Ltd.) manufactures over 400,000 metric tons of standard newsprint each year from southern pine and recycled newspaper and magazines. As part of an energy efficiency review of the mill's boiler system, the company found an ideal application of an ASD to save energy and improve reliability. The boiler's recirculation scrubber was equipped with a 1,100 rpm pump; however, this pump was being driven by a fixed-speed 1,800 rpm motor such that the operators could only adjust the flow of the pump by using an inefficient sheave. The company installed a magnetic drive ASD in this application to better match motor size with flow requirements, with the added benefit of providing operators with more efficient control over pump flow. The new motor reportedly delivered annual cost and energy savings of about $\$ 4,000$ and 114 MWh, respectively [31].

\section{EXAMPLES OF PROCESS-SPECIFIC EFFICIENCY MEASURES}

Table 3 provides a summary of some of the process-specific measures that are presented in the Energy Guide [1].

\section{Raw material preparation}

The processes associated with raw material preparation are estimated to consume roughly $10 \%$ of the electricity use and 3\% of the steam use in U.S. pulp manufacturing operations [16]. One option for reducing the energy use associated with debarking is described below.

Cradle debarker. The cradle debarker is designed to remove bark from de-limbed logs in a manner that reduces debarking energy use by up to 33\% [32]. Reportedly, a cradle debarker works in the following manner: Logs are loaded into a long trough that contains a series of horizontal and vertical conveyor chains, which are oriented at a slight angle to the path of the logs. The chains lift and drop the logs as they move along the trough; this action loosens and removes bark via compressive and shear forces that are generated between the logs in the trough [32]. Additional reported benefits include less damage to logs leading to a greater wood recovery rate, decreased transportation costs through elimination of off-site debarking, and greater process control. The U.S. DOE reports that the cradle debarker can save a mill \$30 per ton of wood in debarking costs [33].

\section{Chemical (Kraft) pulping}

The Energy Guide shows that the vast majority (85\%) of U.S. wood pulp is produced by chemical pulping processes. Furthermore, chemical (i.e., Kraft) pulping and its associated chemical recovery account for the vast majority of steam, electricity, and direct fuel used by the industry in the manufacture of pulp. Efficiency improvements to the chemical pulping process can therefore lead to significant energy savings across the industry. Two such measures are described below 
Table 3: Summary of process-specific energy efficiency measures

\begin{tabular}{|c|c|}
\hline \multicolumn{2}{|c|}{ Raw Material Preparation } \\
\hline Cradle debarkers & Automatic chip handling and screening \\
\hline $\begin{array}{l}\text { Replace pneumatic chip conveyors with belt } \\
\text { conveyors }\end{array}$ & Bar-type chip screening \\
\hline Use secondary heat instead of steam in debarking & Chip conditioning \\
\hline \multicolumn{2}{|c|}{ Chemical Pulping } \\
\hline \multicolumn{2}{|c|}{ Pulping } \\
\hline Use of pulping aids to increase yield & Digester blow/flash heat recovery \\
\hline Optimize the dilution factor control & Heat recovery from bleach plant effluents \\
\hline Continuous digester control system & Improved browstock washing \\
\hline Digester improvement & Chlorine dioxide $\left(\mathrm{ClO}_{2}\right)$ heat exchange \\
\hline \multicolumn{2}{|c|}{ Bleaching } \\
\hline Heat recovery from bleach plant effluents & Chlorine dioxide $\left(\mathrm{ClO}_{2}\right)$ heat exchange \\
\hline Improved brownstock washing & \\
\hline \multicolumn{2}{|c|}{ Chemical Recovery } \\
\hline Lime kiln oxygen enrichment & Improved composite tubes for recovery boiler \\
\hline Lime kiln modification & Recovery boiler deposition monitoring \\
\hline Lime kiln electrostatic precipitation & Quaternary air injection \\
\hline Black liquor solids concentration & \\
\hline \multicolumn{2}{|c|}{ Mechanical Pulping } \\
\hline Refiner improvements & Increased use of recycle pulp \\
\hline Refiner optimization for overall energy use & Heat recovery from de-inking plant \\
\hline Pressurized groundwood & Fractionation of recycled fibers \\
\hline Continuous repulping & Thermopulping \\
\hline Efficient repulping rotors & RTS pulping \\
\hline Drum pulpers & Heat recovery in TMP \\
\hline \multicolumn{2}{|c|}{ Papermaking } \\
\hline Advanced dryer controls & Waste heat recovery \\
\hline Control of dew point & Vacuum nip press \\
\hline Energy efficient dewatering - rewetting & Shoe (extended nip) press \\
\hline Dryers bars and stationary siphons & Gap forming \\
\hline Reduction of blowthrough losses & CondeBelt drying \\
\hline Reduction air requirements & Air impingement drying \\
\hline Optimizing pocket ventilation temperature & \\
\hline
\end{tabular}

Digester heat recovery. In the Kraft chemical pulping process, steam is produced when hot pulp and cooking liquor is reduced to atmospheric pressure at the end of the cooking cycle. In batch digesters, steam is typically stored as hot water in an accumulator tank. In continuous digesters, extracted black liquor flows to a tank where it is flashed [34]. Recovered heat from these processes can be used in other facility applications, such as chip pre-steaming, facility water heating, or black liquor evaporation [34, 25].

For black liquor evaporation, flash steam from batch digester blow (created by flashing from the hot water accumulator) or black liquor flash from a continuous digester can used for thermal energy in a multi-stage evaporator. This thermal energy will offset the need for steam generated by a boiler for black liquor evaporation [34].

In chip steaming, the black liquor that is flashed in stages from continuous digesters can be used in two ways. Flash vapor from the first stage is normally used to heat the chips in the steaming vessel, while the flash vapor of the second stage can be used instead of live steam in the chip bin [34]. Reportedly, the use of flash steam in the chip bin been proven out at several North American mills; however, U.S. regulations state that the vent from the chip bin has to be collected and treated if flash steam is used for chip preheating [34]. 
A plant-wide energy audit of Georgia-Pacific's mill in Crossett, Arkansas, recommended improving blow heat recovery from the mill's two parallel batch digester lines. At the time of the audit, a cooling tower was used to remove excess heat from the blow steam accumulator and a steam heater was used to generate hot water for the bleach plant [35]. The audit team recommended installing new heat exchangers and rerouting water lines such that the cooling tower and steam heater could be shut down. It was estimated that this project would save 940,000 MMBtu of fuel, 705,000 MMBtu of natural gas, and \$2,350,000 in costs each year with a payback period of around one year [35].

At the Weyerhaeuser pulp and paper mill in Longview, Washington, the proposed addition of a digester heat recovery system was expected to result in annual natural gas savings of 130,000 MMBtu, leading to $\$ 280,000$ per year in cost savings [36].

Black liquor solids concentration. Black liquor concentrators are designed to increase the solids content of black liquor prior to combustion in a recovery boiler. Increased solids content means less water must be evaporated in the recovery boiler, which can increase the efficiency of steam generation substantially. There are two primary types in use today: submerged tube concentrators and falling film concentrators.

In a submerged tube concentrator, black liquor is circulated in submerged tubes where it is heated but not evaporated; the liquor is then flashed to the concentrator vapor space, causing evaporation [34]. An analysis by NCASI suggests that for a 1,000 ton per day pulp plant, increasing the solid content in black liquor from $66 \%$ to $80 \%$ would lead to fuel savings of $30 \mathrm{MMBtu} /$ hour, or roughly $\$ 550,000$ [34]. Capital costs of the high solids concentrator will include concentrator bodies, piping for liquor and steam supplies, and pumps.

A tube type falling film evaporator effect operates almost exactly the same way as a more traditional rising film effect, except that the black liquor flow is reversed. The falling film effect is more resistant to fouling because the liquor is flowing faster and the bubbles flow in the opposite direction of the liquor. This resistance to fouling allows the evaporator to produce black liquor with considerably higher solids content (up to $70 \%$ solids rather than the traditional $50 \%$ ), thus eliminating the need for a final concentrator [37]. Martin et al. [11] estimate a steam savings of $0.8 \mathrm{GJ}$ per tonne of pulp [38].

A U.S. pulp and paper mill with 900 ton paper production per day installed a liquor concentrator to increase its solids content from $73 \%$ to $80 \%$. This increase results in annual energy savings of about 110,000 MMBtu. Costs saving were about $\$ 900,000 /$ year, leading to an estimated period of payback of 4 years [1].

\section{Papermaking}

The papermaking process accounts for about half of the total steam, electricity, and direct fuel used by the U.S. pulp and paper industry [16]. In particular, the drying stage of the paper machine accounts for the vast majority of thermal energy use in papermaking. Most energy saving opportunities for papermaking are therefore related to improving the efficiency of the drying process and recovering its waste heat for beneficial use. Four example measures are provided below.

Advanced dryer controls. Control systems are a well-known way to optimize process variables and thereby reduce energy consumption, increase productivity, and improve the quality of industrial processes. One example of a control system for dryers is Dryer Management System ${ }^{\mathrm{TM}}$ control software, which reportedly offers advanced control of dryer system set points and process parameters to reduce steam use and improve productivity $[25,39,40]$. Several case studies of this technology are available in the literature.

Focus on Energy [39] describes a pilot of the Dryer Management System software at a Stora Enso mill in Steven's Point, Wisconsin. The mill's paper machine was metered to determine energy savings, which were deemed quite significant: 4,500 pounds of steam per hour, which were estimated to lead to $\$ 360,000$ in annual energy cost savings [39]. Additionally, the company reportedly experienced significant improvement with product quality and throughput. The payback period was estimated at under 3 years based on energy savings alone (i.e., no consideration of productivity benefits) [39]. 
Reese [40] describes results from another Stora Enso installation of Dryer Management System software, this time on a Voith lightweight coated machine with two on-machine coalers. Reportedly, annual savings of $\$ 263,000$ were observed due to reduced energy consumption, lower maintenance cost, and higher production. The reported payback period was seven months [40].

Waste heat recovery. In the paper drying process, several opportunities exist to recover thermal energy from steam and waste heat. One mill replaced the dryers with stationary siphons in their paper machine and was able to achieve energy savings of $0.89 \mathrm{GJ} / \mathrm{t}$ due to improved drying efficiency, with an operation cost savings of $\$ 25,000(\$ 0.045 / t)$ [11]. A second system used mechanical vapor recompression in a pilot facility to reuse superheated steam into the drying process [41]. Steam savings for this approach were up to $5 \mathrm{GJ} / \mathrm{t}(50 \%)$ with additional electricity consumption of $160 \mathrm{kWh} / \mathrm{t}$ [41]. A third system noted in the literature was the use of heat pump systems to recover waste heat in the drying section [42]. Martin et al. [11] estimates that team energy savings of around 0.4 MMBtu/ton of paper are achievable through paper machine heat recovery, with installation costs of around \$18 per tonne of paper. However, the installation of heat recovery systems will lead to more maintenance since heat exchangers require periodic cleaning.

Heat can also be recovered from the ventilation air of the drying section and used for heating of the facilities [43]. For example, a mill-wide energy assessment Appleton Paper's mill in West Carrollton, Ohio, found that the recovery of paper machine vent heat could be used for heating the plant in winter months. I was recommended that cross-flow heat exchangers be installed to generate hot air for plant heating from recovered heat in the paper machine vent exhaust gas. The estimated annual cost savings were about $\$ 1,000,000$. With investment costs of about $\$ 1,500,000$, the payback period was estimated at only 1.5 years [44].

Another reported opportunity is to recovery heat from Uhle box effluents. At the Blue Heron Paper Company mill in Oregon City, Oregon, the Uhle box removes a combination of shower water and water from the sheet at a temperature between $115^{\circ} \mathrm{F}$ and $120^{\circ} \mathrm{F}$. A heat recovery project identified for this Uhle box estimated annual energy savings of 32,000 MMBtu, with estimated costs savings around \$100,000. Capital costs were estimated at around $\$ 110,000$, leading to a payback period of around one year [45].

Shoe (extended nip) press. After paper is formed, it is pressed to remove as much water as possible. Normally, pressing occurs between two felt liners pressed between two rotating cylinders. Extended nip presses use a large concave shoe instead of one of the rotating cylinders. The additional pressing area allows for greater water extraction, (about 5-7\% more water removal) to a level of 35-50\% dryness [11]. Greater water extraction leads to decreased energy requirements in the dryer, which leads to reductions in steam demand. Furthermore, reduced dryer loads allow plants to increase capacity up to 25\% in cases where production is dryer limited [11]. Extended nip pressing also increases wet tensile strength [46].

Published estimates for the steam savings achievable through the installation of extended nip presses range from $2 \%$ to around $15 \%$, depending on product and plant configuration [11, 25]. For example, the application of the X-NIP T shoe press in tissue plants is estimated to reduce drying energy use by 15\% [47]. Capital costs have been estimated at $\$ 38$ per tonne of paper and additional maintenance costs have been estimated at \$2.24 per tonne of paper [48].

Reduced air requirements. Air to air heat recovery systems on existing machines recover only about $15 \%$ of the energy contained in the hood exhaust air [11]. This percentage could be increased to $60-70 \%$ for most installations with proper maintenance and extensions of the systems. Paper machines with enclosed hoods require about one-half the amount of air per tonne of water evaporated compared to paper machines with a canopy hoods. Enclosing the paper machine reduces thermal energy demands since a smaller volume of air is heated. Electricity requirements in the exhaust fan are also reduced [38].

Published estimates suggest steam savings of $0.76 \mathrm{GJ}$ per tonne of paper and electricity savings of $6.3 \mathrm{kWh}$ per tonne of paper by installing a closed hood and an optimized ventilation system. Investment costs and operations and maintenances costs have been reported at $\$ 9.5 / \mathrm{t}$ paper and $\$ 0.07 / \mathrm{t}$ paper, respectively [11]. 


\section{SUMMARY}

The U.S. pulp and paper industry spent roughly $\$ 7.5$ billion on purchased fuels and electricity in 2006, making energy a significant cost driver for the industry. Energy efficiency improvement is an important way to reduce these costs and to increase predictable earnings in the face of ongoing energy price volatility. Many companies in the U.S. pulp and paper industry have already accepted the challenge to improve their energy efficiency in the face of high energy costs and have begun to reap the rewards of energy efficiency investments.

The Energy Guide summarizes a large number of energy-efficient technologies and practices that are proven, cost-effective, and available for implementation today. Energy efficiency improvement opportunities are discussed that are applicable at the component, process, facility, and organizational levels. Preliminary estimates of savings in energy and energy-related costs are provided for many energy efficiency measures, based on case study data from real-world industrial applications. Additionally, typical investment payback periods and references to further information in the technical literature have been provided, when available.

It is hoped the Energy Guide can be used by energy managers in the U.S. pulp and paper industry to identify areas for energy efficiency improvements, to evaluate potential energy improvement options, to develop action plans and checklists for plant-level energy management, and to educate company employees on the importance of and actions for improved energy efficiency.

New and improved technologies for pulp and paper mills are being developed and evaluated continuously, many of which can provide not only energy savings, but also water savings, increased reliability, reduced emissions to water and air, higher paper quality, and improved productivity.

\section{ACKNOWLEDGMENTS}

This work was supported by the Climate Protection Partnerships Division of the U.S. Environmental Protection Agency as part of its ENERGY STAR program through the U.S. Department of Energy under Contract No. DE-AC02-05CH11231.

\section{REFERENCES}

[1] Kramer, K.J., E. Masanet, and E. Worrell (2008). Energy Efficiency Improvement and Cost Saving Opportunities for the Pulp and Paper Industry -- An ENERGY STAR Guide for Energy and Plant Managers. Lawrence Berkeley National Laboratory Berkeley, California. Forthcoming.

[2] United States Census Bureau (2008). Annual Survey of Manufactures Data: 2006. United States Department of Commerce, Washington, D.C. Available online at: http://factfinder.census.gov/

[3] United States Census Bureau (2008). County Business Patterns Database. United States Department of Commerce, Washington, D.C. Available online at: http://www.census.gov/epcd/cbp/view/cbpview.html

[4] Kincaid, J. (Ed.) (1998) 1998 North American Pulp \& Paper Fact Book. Miller Freeman Publications, San Francisco, California.

[5] United States Environmental Protection Agency (EPA) (2002). Profile of the Pulp and Paper Industry, 2nd Edition. Office of Enforcement and Compliance Assurance, Washington, D.C. Report: EPA/310R-02-002.

[6] United States Census Bureau (2001). 1997 Economic Census, Concentration Ratios in Manufacturing. United States Department of Commerce, Washington, D.C. Report EC97M31S-CR.

[7] Food and Agricultural Organization of the United Nations (FAO-UN), 2007. FAOSTAT

[8] United States Census Bureau (2008). CenStats Database: International Trade Data. United States Department of Commerce, Washington, D.C. Available online at: http://censtats.census.gov/

[9] United States Department of Energy (DOE) (2005). Energy and Environmental Profile of the U.S. Pulp and Paper Industry. Office of Energy Efficiency and Renewable Energy, Industrial Technologies Program, Washington, D.C. DOE/GO-102004-1758.

[10] Energy and Environmental Analysis (EEA) (2005). Characterization of the U.S. Industrial/Commercial Boiler Population. Report Submitted to Oak Ridge National Laboratory, Oak Ridge, Tennessee. May. 
[11] Martin, N., N. Anglani, D. Einstein, M. Khrushch, E. Worrell, and L.K. Price (2000). Opportunities to Improve Energy Efficiency and Reduce Greenhouse Gas Emissions in the U.S. Pulp and Paper Industry. Lawrence Berkeley National Laboratory, Berkeley, California. Report LBNL-46141.

[12] United States Census Bureau (2006). Annual Survey of Manufactures, Statistics for Industry Groups and Industries: 2005. United States Department of Commerce, Washington, D.C. Report M05(AS)-1

[13] United States Census Bureau (2003). Annual Survey of Manufactures, Statistics for Industry Groups and Industries: 2001. United States Department of Commerce, Washington, D.C. Report M01(AS)-1

[14] United States Department of Energy (DOE). (2008). Natural Gas Navigator: U.S. Industrial Natural Prices 1997-2007. Energy Information Administration, Washington, D.C. Available online at: http://www.eia.doe.gov/oil_gas/natural_gas/info_glance/natural_gas.html

[15] United States Department of Energy (DOE). (2007). 2002 Manufacturing Energy Consumption Survey. Energy Information Administration, Washington, D.C. Available online at: http://www.eia.doe.gov/emeu/mecs/

[16] Jacobs and IPST (2006). Pulp and Paper Industry. Energy Bandwidth Study. Report for American Institute of Chemical Engineers (AIChE). Jacobs Greenville and Institute of Paper Science and Technology (IPST) at Georgia Institute of Technology, Atlanta.

[17] United States Department of Energy (DOE) (2002). Steam System Opportunity Assessment for the Pulp and Paper, Chemical Manufacturing, and Petroleum Refining Industries. Main Report. Energy Efficiency and Renewable Energy, U.S. Department of Energy. DOE/GO-102002-1639.

[18] Industrial Assessment Centers (IAC) (2008). Industrial Assessment Centers Database. Rutgers University, New Brunswick, New Jersey. http://iac.rutgers.edu/database/

[19] United States Department of Energy (DOE) (2002). Forest Products. Best Practices Assessment Case Study. Appleton Paper Plants-Wide Energy Assessment Saves Energy and Reduces Waste. Office of Energy Efficiency and Renewable Energy, Industrial Technologies Program, Washington, D.C. DOE/GO-102002-1512.

[20] United States Department of Energy (DOE) (2004). Improving Steam System Performance. A Sourcebook for Industry. Office of Energy Efficiency and Renewable Energy, Industrial Technologies Program, Washington, D.C. DOE/GO-102004-1868.

[21] Ganapathy, V. (1994). Understand Steam Generator Performance. Chemical Engineering Progress. December.

[22]Zeitz, Ronald A. (Ed.) (1997). CIBO Energy Efficiency Handbook. Council of Industrial Boiler Owners, Burke, Virginia.

[23] United States Department of Energy (DOE) (2006). FINAL Public Release Report for the Boise Cascade Energy Savings Assessment (ESA 006). Office of Energy Efficiency and Renewable Energy, Industrial Technologies Program, Washington, D.C.

[24] United States Department of Energy (DOE) (2008). Save Energy Now, Industrial Technology Program Case Study. Longest-Serving Active Paper Mill in the Western United States Uncovers New Ways to Save Energy. Office of Energy Efficiency and Renewable Energy, Industrial Technologies Program, Washington, D.C.

[25] Focus on Energy (2006). Pulp and Paper Energy Best Practice Guidebook. Madison, Wisconsin. ISBN: 1-59510-120-9.

[26] United States Department of Energy (DOE) (2002). Forest Products. Best Practices Assessment Case Study. Boiler Blowdown Heat Recovery Project Reduces Steam System Energy Losses at Augusta Newsprint. Office of Energy Efficiency and Renewable Energy, Industrial Technologies Program, Washington, D.C. DOE/GO-102002-1536.

[27] United States Department of Energy (DOE) (2006). Boise Cascade International Falls Public Report (ESA 019). Office of Energy Efficiency and Renewable Energy, Industrial Technologies Program, Washington, D.C.

[28] Austin, P., M. McEwan, J. Mack, J. Godsal and J. Tyler (2008). Optimisation of Fuel Usage and Steam in the Power \& Steam Plant at a Paper Mill using Advanced Process Control. Proceedings COST Strategic Workshop "Improving Energy Efficiency in Papermaking" Amsterdam Airport, The Netherlands. June 9-11th, 2008.

[29] United States Department of Energy (DOE) (2002). United States Industrial Electric Motor Systems Market Opportunities Assessment. Office of Energy Efficiency and Renewable Energy, Office of Industrial Technologies, Washington, D.C. 
[30]Worrell, E., J.W. Bode, and J.G. de Beer (1997). Energy Efficient Technologies in Industry Analysing Research and Technology Development Strategies - The 'Atlas' Project. Department of Science, Technology \& Society, Utrecht University, Utrecht, The Netherlands.

[31] United States Department of Energy (DOE) (2002). Forest Products. Best Practices Assessment Case Study. Four Equipment Upgrade Projects Reduce System Energy Losses at Augusta Newsprint. Office of Energy Efficiency and Renewable Energy, Industrial Technologies Program, Washington, D.C. DOE/GO-102002-1535.

[32] United States Department of Energy (DOE) (2002). Forest Products. Success Stories. Removal of Bark from Whole Logs. Office of Weatherization and Intergovernmental Program Energy Efficiency and Renewable Energy U.S. Department of Energy Washington, D.C.Order \# I-FP-653.

[33] United States Department of Energy (DOE) (2007). Removal of Bark from Whole Logs. New Technology Saves Trees, Increases Product Value, and Lowers Production Costs. Office of Energy Efficiency and Renewable Energy, Industrial Technologies Program, Washington, D.C.

[34] National Council for Air and Stream Improvement (NCASI) (2001). Technologies for Reducing Carbon Dioxide Emissions: A Resource Manual for Pulp, Paper and Wood Products Manufacturers. Special Report No. 01-05. Research Triangle Park, North Carolina.

[35] United States Department of Energy (DOE) (2003). Forest Products. BestPractices Plant-Wide Assessment Case Study. Georgia-Pacific: Crosset Mill Identifies Heat Recovery Projects and Operations Improvements that May Save \$9.6 Million Annually. Office of Energy Efficiency and Renewable Energy, Industrial Technologies Program, Washington, D.C. DOE/GO-102003-1722.

[36] United States Department of Energy (DOE) (2004). Forest Products. BestPractices Plant-Wide Assessment Case Study. Weyerhaeuser Company: Longview Mill Conducts Energy and Water Assessment that Finds Potential for \$3.1 Million in Annual Savings. Office of Energy Efficiency and Renewable Energy, Industrial Technologies Program, Washington, D.C. DOE/GO-102004-1809.

[37] Nilsson, L, E. Larson, K. Gilbreath and A. Gupta. (1995). Energy Efficiency and the Pulp and Paper Industry. American Council for an Energy Efficient Economy. Washington D.C.

[38] Elaahi, A. and H.E. Lowitt (1988). The U.S. Pulp and Paper Industry: An Energy Perspective. U.S. Department of Energy, Washington, D.C.

[39] Focus on Energy (2006). Pulp \& Paper Industry Case Studies. Dryer Management System. Wisconsin Focus on Energy. BP-3186-0106. Madison, Wisconsin

[40] Reese, D. (2005). Low-Cost Dryer Upgrade Opportunities Offer Efficiency Gains, Energy Saving. Pulp \& Paper, March.

[41] Van Deventer, H.C. (1997) Feasibility of Energy Efficient Steam Drying of Paper and Textile Including Process Integration. Applied Thermal Engineering 17 (8-10), pp 1035-1041.

[42] Abrahamson, K., S. Stenstrom, G. Aly and A. Jernquist (1997). Application of Heat Pump Systems for Energy Conservation in Paper Drying. International Journal of Energy Research. Vol. 21 pp. 631-642.

[43]De Beer, J.G., M.T. van Wees, E. Worrell and K. Blok (1994). Icarus-3: The Potential of Energy Efficiency Improvements in the Netherlands up to 2000 and 2015. Utrecht University, Department of Science, Technology and Society. Utrecht, The Netherlands.

[44] United States Department of Energy (DOE) (2002). Forest Products. Best Practices Assessment Case Study. Appleton Paper Plants-Wide Energy Assessment Saves Energy and Reduces Waste. Office of Energy Efficiency and Renewable Energy, Industrial Technologies Program, Washington, D.C. DOE/GO-102002-1512.

[45] United States Department of Energy (DOE) (2004). Forest Products. BestPractices Plant-Wide Assessment Case Study. Blue Heron Paper Company.: Oregon Mills Uses Mode-Based Energy Assessment to Identify Energy and Cost Saving Opportunities. Office of Energy Efficiency and Renewable Energy, Industrial Technologies Program, Washington, D.C. DOE/GO-102004-1758.

[46] Lange, D. and M. Radtke (1996). Extended Nip Pressing of Paper Grades: A Technical Summary. Beloit Corporation, Beloit, Wisconsin.

[47] Baubock, J. and A. Anzel (2007). Reduce your drying costs. Steel Yankee and shoe press make a more attractive alternative to conventional technology, as energy costs rise. Tissue World Magazine, December 2007/January 2008.

[48] De Beer, J.G., M.T. van Wees, E. Worrell and K. Blok (1994). Icarus-3: The Potential of Energy Efficiency Improvements in the Netherlands up to 2000 and 2015. Utrecht University, Department of Science, Technology and Society. Utrecht, The Netherlands. 


\section{ABOUT THE AUTHORS}

Klaas Jan Kramer, Ph.D. is a guest researcher at Lawrence Berkeley National Laboratory. Previously he has worked at the Center for Energy and Environmental Studies of the University of Groningen (The Netherlands) and the Agricultural Economic Research Institute of the Wageningen University (The Netherlands). His work includes research and evaluation projects in industrial energy efficiency improvement, energy and greenhouse gas emission assessment and reductions as well as Life Cycle Assessments. Contact: Energy Analysis Department, Lawrence Berkeley National Laboratory, Mail Stop 90-4000, Berkeley, CA 94720 USA. Telephone: (510) 486-4228. Fax:

(510) 486-6996. E-mail: KJKramer@lbl.gov

Eric Masanet, Ph.D. is a principal scientific/engineering associate in the International Energy Studies Group at Lawrence Berkeley National Laboratory. His research areas include life-cycle assessment of products and industrial systems, industrial energy demand and efficiency analysis, and the development of models for evaluating product- and process-related energy efficiency and greenhouse gas mitigation strategies in various geographic regions. Eric holds a joint research appointment at the University of California, Berkeley, where he currently serves as Program Manager for the UC Berkeley Engineering and Business for Sustainability (EBS) Certificate Program. Contact: Energy Analysis Department, Lawrence Berkeley National Laboratory, 1 Cyclotron Road, Building 90R4000, Berkeley, California, 94720. Phone: (510)486-6794. Email: ermasanet@lbl.gov.

Ernst Worrell, Ph.D. is Professor 'Energy, Materials \& the Environment' at Utrecht University (The Netherlands) and Manager Energy Efficiency at Ecofys (The Netherlands), as well as staff scientist at Lawrence Berkeley National Laboratory. His work includes research and evaluation projects in industrial energy efficiency improvement, greenhouse gas emission mitigation in industry, energy efficiency benchmarking, energy policy, energy modeling, emission trading, energy and materials, and waste processing. Contact: Ecofys, PO Box 8408, NL-3503 RK, Utrecht, The Netherlands. Phone: +1-31-306623374. Email: e.worrell@ecofys.com 